\title{
TRANSFORMASI SOSIAL DESA ADAT MENJADI DESA WISATA EDELWEIS: PERPEKTIF TEORI STRUKTURISASI "ANTHONY GIDDENS"
}

\author{
Setiyo Yuli Handono*
}

\begin{abstract}
ABSTRAK
Fenomena perubahan sosial yang terjadi di Desa Wonokitri, Kec Tosari, Kab Pasuruan sangat terasa mulai dari tahun 2000 awal sampai dengan 2019. Perubahan tidak hanya merubah kondisi fisik bahkan secara social dan ekonomi juga berubah sangat pesat. Perubahan tersebut terjadi melalui perencanaan dan peranan dari pihak-pihak dari internal maupun eksternal. Rumusan masalah meliputi: 1) siapa agen dan struktur dalam perubahan sosial Desa Wonokitri (sebelumnya terkenal Desa Adat) menjadi Desa Wisata, 2) bagaimana peran dari agen dan struktur dalam perubahan sosial, 3) bagaimana hubungan yang terjalin antara agen dengan struktur dalam perubahan sosial. Analisis dalam penelitian menggunakan teori strukturasi Anthony Giddens yang menjelaskan konsep agen dan struktur, ruang dan waktu, serta hubungan struktur dengan praktik sosial agen. Jenis penelitian ini adalah penelitian kualitatif dengan metode studi kasus. Pengumpulan data menggunakan observasi, yakni mengamati kondisi lingkungan desa dan berbagai praktik sosial agen serta masyarakat Wonokitri berkaitan dengan konteks penelitian, wawancara terhadap informan utama dan tambahan, serta mengumpulkan berbagai dokumentasi. Hasil penelitian menunjukkan terdapat tiga agen utama (kalangan tayuban/teropan: pardi, dan budi, kalangan wisata jeep dan homestay: sukir) dari masyarakat Wonokitri yang memiliki pengaruh di masyarakat. Peran yang dilakukannya dalam perubahan sosial adalah dengan sosialisasi, berkoordinasi, bersinergi dan kerjasama. Struktur yang ada berasal dari masyarakat Wonokitri beserta praktik sosialnya yang dilatarbelakangi kesadaran praktis dan diskursifnya serta peran tokoh masyarakat (Kepala Desa: Pak Iksan), tokoh adat (Ketua Adat: Pak Kadik) melalui kebijakan strukturalnya. Hubungan antara agen dengan struktur dalam perubahan terjadi melalui skema struktur dominasi (penguasaan agen terhadap struktur), berlanjut signifikansi (ajakan agen pada struktur), dan mencapai skema legitimasi (pembenaran atas upaya agen oleh struktur).
\end{abstract}

Kata Kunci: agen perubahan, struktur, peran agen dan struktur 


\begin{abstract}
The phenomenon of social change that occurred in Wonokitri Village, Sub-District of Tosari, Pasuruan Regency was very pronounced from the early 2000s until 2019. Changes not only change physical conditions even socially and economically also change very rapidly. These changes occur through planning and the role of parties from internal and external. The formulation of the problem includes: 1) who are the agents and structures in social change? Wonokitri Village (formerly known as Desa Adat) becomes a Tourism Village; The analysis in this research uses Anthony Giddens' structuration theory which explains the concept of agent and structure, space and time, as well as the relationship of structure with agent's social practice. This type of research is qualitative research with a case study method. Data collection uses observation, which is observing the condition of the village environment and various social practices of agents and the Wonokitri community in relation to the research context, interviews with key and additional informants, and gathering various documentation. The results showed that there were three main agents (tayuban / teropan: pardi and budi, jeep tourism and homestay: sukir) from the Wonokitri community who had influence in the community. The role he does in social change is through socialization, coordination, synergy and cooperation. The existing structure comes from the Wonokitri community and their social practices which are motivated by their practical and discursive awareness as well as the role of community leaders (Village Head: Pak Iksan), traditional leaders (Customary Chair: Pak Kadik) through their structural policies. The relationship between the agent and the structure in change occurs through the scheme of domination structure (control of the agent over the structure), continuing significance (the invitation of the agent to the structure), and achieving the scheme of legitimacy (justification for the agent's efforts by the structure).
\end{abstract}

Keywords: agents of change, structure, the role of agents and structure, the relationship of agents with structures in social changes

Keywords: agent of change, structure, agent role and structure

\section{PENDAHULUAN}

Perubahan adalah suatu hal yang tidak bisa dihindari dalam kehidupan manusia dan menjadi suatu kewajaran. Kehidupan manusia akan selalu mengalami dinamika perubahan sebagai konsekuensi dari hubungan antar manusia dalam masyarakat. Comte mengatakan bahwa masyarakat merupakan kelompokkelompok makhluk hidup dengan realitas baru yang berkembang menurut hukumnya sendiri dan memiliki pola perkembangan tersendiri (Syani, 2007). Berdasarkan pernyataan Comte tersebut, dapat 
digarisbawahi bahwa masyarakat mengalami perkembangan berdasarkan hukum atau aturan yang mereka ciptakan sendiri dan akan selalu berkembang dengan pola tertentu. Perkembangan inilah yang menandakan bahwa kehidupan manusia selalu mengalami perubahan dari suatu kondisi ke kondisi lainnya.

Syani (2007) mendefinisikan perubahan sosial yakni perubahan fungsi kebudayaan dan perilaku manusia dalam masyarakat dari keadaan tertentu ke keadaan yang lain. Sementara Ritzer (dalam Sztompka, 2010) menyatakan bahwa perubahan sosial mengacu pada variasi hubungan antar individu, kelompok, organisasi, kultur dan masyarakat pada waktu tertentu. Kedua definisi tersebut menunjukkan bahwa yang menandai terjadinya perubahan sosial adalah adanya perubahan variasi pada perilaku hubungan antar individu dan budayanya pada waktu tertentu, sehingga untuk melihat terjadinya perubahan, maka harus membandingkan keadaan perilaku hubungan antar individu dan kebudayaannya saat ini dengan keadaan sebelumnya. Jika dalam keadaan yang dibandingkan terdapat perbedaan, maka dipastikan telah terjadi perubahan sosial di masyarakat.

Perubahan sosial dalam realitasnya di masyarakat dibagi dalam dua cara, yakni perubahan yang direncanakan dan perubahan yang tidak direncanakan (Syani,
2007). Perubahan sosial yang direncanakan adalah perubahan-perubahan terhadap lembaga kemasyarakatan yang didasarkan pada perencanaan yang matang oleh pihakpihak yang menginginkan adanya perubahan tersebut dan cenderung bersifat ke arah yang lebih baik, sementara perubahan sosial yang tidak direncanakan adalah perubahan yang berlangsung di luar kehendak dan pengawasan masyarakat dan keberadaannya cenderung tidak dikehendaki karena mengarah pada dampak negatif.

Perubahan sosial yang direncanakan salah satunya pada fenomena perubahan di Desa Wonokitri, yang mana sebagai akibat dari perubahan yang dimulai sejak tahun 2000, Kepala Desa yang lama bekerjasama dengan berbagai stakholders khususnya pemerintah pusat untuk membuka acces jalan desa untuk wisata menuju Penanjakan, Kawah Bromo dan lainnya. Bahkan pada tahun 2016 telah diresmikan Taman Edelweis TNBTS di Musola BSM Penanjakan yang berada di RPTN Gunung Penajakan oleh Ibu Menteri Lingkungan Hidup dan Kehutanan (Siti Nurbaya Bakar). Taman Edelweis juga berfungsi sebagai taman percontohan dan disiapkan sebagai sumber benih Edelweis bagi masyarakat Desa Wonokitri tersebut, Berbeda dengan kodisi wonokitri sebelum terjadinya perubahan sosial (sebelum era 2000, yang hanya terkenal desa adat saja) 
yang mana kondisinya dianggap stagnan aspek ekonomi dari saat ini setelah mengalami perubahan khususnya aspek ekonomi, social. Namun hal tersebut juga menjadi ancaman bagi masyarakat Desa Wonokitri yaitu aspek adat maupun lingkungan menjadi rusak. Serta ada jurang kecemburuan social antara si kaya dan si miskin. Sehingga akan timbul disharmonisasi atau konflik sesama warga di Desa Wonokitri.

Perubahan Desa Wonokitri dari tahun 2000 s.d 2019 memang sangat pesat dari aspek pembangunan home stay, perkembangan kepemilikan jeep, warung, dan lain-lainnya. Sehingga Desa Wonokitri ini juga berpotensi menjadi desa wisata yang ramah lingkungan (taman edelweiss) sehingga apakah mampu Desa Wonokitri menjadi Desa Wisata yang ramah lingkungan atau malah terjadi hal yang tidak diinginkan oleh berbagai pihak.

Secara umum, artikel ini membahas mengenai perubahan sosial yang terjadi di Desa Wonokitri sehingga dikenal sebagai Desa Wisata yang ASRI. Fakta mengenai adanya kontradiksi yang jauh antara kondisi awal Wonokitri yang masih belum tersentuh wisata dibandingkan dengan kondisi yang sekarang sangat ramai dengan wisatawan. Hal tersebut karena perubahan yang terjadi tidak hanya pada tataran fisik lingkungannya saja, tetapi juga berdampak pada masyarakatnya sehingga menarik untuk dikaji secara rinci agar dapat mengetahui dan mengklasifikasikan perubahan sosial yang terjadi di Wonokitri.

Berdasarkan latar belakang penelitian tersebut, sehingga penulis mengklasifikasikan 3 rumusan masalah, yakni: 1) siapa agen dan struktur dalam perubahan sosial Desa Wonokitri menjadi Desa Wisata, 2) bagaimana peran dari agen dan struktur dalam perubahan sosial, 3) bagaimana hubungan yang terjalin antara agen dengan struktur dalam perubahan sosial.

Tulisan ini digunakan teori strukturasi Anthony Giddens untuk menganalisis. Teori tersebut memberi penjelasan mengenai konsep agen dan struktur, ruang dan waktu, serta konsep hubungan struktur dan praktik sosial. Konsep mengenai agen dan struktur dalam perubahan digunakan untuk mengidentifikasi pihak yang terlibat perencanaan dan proses perubahan sosial. Konsep ruang dan waktu mempermudah mengetahui ruang dan waktu yang menjadi setting dan unsur konstitutif perubahan sosial. Sedangkan konsep hubungan struktur dan praktik sosial yang juga menjelaskan tentang konsep kesadaran digunakan untuk mengetahui bentuk hubungan yang terjalin antara agen dan struktur selama proses perubahan sosial berlangsung. 


\section{METODE PENELITIAN}

Metode penelitian yang digunakan berjenis kualitatif untuk memahami fenomena yang dialami subjek penelitian secara holistik dengan cara mendeskripsikan dalam kata-kata (Moleong, 2013). Pendekatan penelitian menggunakan studi kasus karena peneliti memiliki sedikit peluang untuk mengontrol peristiwa yang akan diselidiki dan fenomena penelitian merupakan fenomena masa kini dalam kehidupan nyata (Yin, 2013). Tipe studi kasus yang digunakan adalah studi kasus deskriptif intrinsik karena bertujuan untuk memahami dan menggambarkan fokus penelitian sebagaimana terdapat pada rumusan masalah secara lebih baik (Salim, 2006). Analisis data menggunakan Teknik komparasi antara empiris dengan telaah teori (Yin, 2003).

Penentuan informan penelitian menggunakan teknik purposif dengan cara menentukan informan yang dianggap representatif terhadap kriteria yang ditentukan peneliti (Salim, 2006). Kriteria tersebut yakni: 1) mereka yang dijadikan informan memahami sejarah, gambaran umum dan perubahan yang terjadi di Desa Wonokitri serta benar-benar merupakan penduduk yang lama menetap atau penduduk asli kelurahan tersebut, 2) mengetahui dan terlibat dalam fokus permasalahan yang dikaji, dan 3) memiliki waktu luang yang memadai untuk dimintai keterangan. Atas pertimbangan tersebut, peneliti mengklasifikasikan dua tipe informan, yakni: 1) informan utama, yang mana mengetahui dan dapat menjelaskan secara rinci terhadap fenomena yang diteliti serta terlibat secara penuh dalam fenomena. Informan utama juga berfungsi untuk menemukan akses terhadap sumber-sumber bukti penelitian lainnya. Informan utama dalam penelitian ini terdiri dari satu orang pejabat Kepala Desa dan 3 orang yang dianggap menjadi inisiator (agen pencetus perubahan), serta 1 orang tokoh adat, 2 orang fasilitator. 2) informan pendukung, yang mengetahui dan terlibat langsung, namun tidak secara penuh dalam fenomena yang diteliti yang mana dijadikan sebagai sumber untuk mengklarifikasi sumbersumber lainnya. Informan tambahan di sini terdiri dari 2 orang masyarakat Wonokitri pada umumnya yang mengetahui adanya perubahan di desa tersebut.

\section{Bentuk dan Tahapan Perubahan Sosial di Desa Wonokitri}

Berdasarkan monografi Desa Wonokitri tahun 2014, Desa Wonokitri secara topografi berada pada wilayah dan bentang alam mulai dataran (30\%) sampai perbukitan dan pegunungan $(70 \%)$ dengan ketinggian sekitar 1900 meter dpl. Dengan curah hujan $2200 \mathrm{~mm}$ per tahun menjadikan desa ini memiliki jumlah bulan hujan 
sebayak 6 bulan selama setahun. Suhu udara maksimal di sekitar desa wonokitri 23 derajat celcius dan suhu udara minimal 16 derajat celcius.

Jumlah penduduk desa Wonokitri sebanyak 3032 jiwa yang terdiri dari lakilaki sebanyak 1497 jiwa dan perempuan sebanyak 1535 jiwa dan terdiri dari 685 Kepala Keluarga. Dengan jumlah penduduk tersebut, $90 \%$ nya adalah memiliki mata pencaharian sebagai petani, sedangan $5 \%$ sebagai buruh tani dan sisanya $5 \%$ profesi sebagai pedagang.

Januari 2018， 8 Pemuda Desa Wonokitri telah ujicoba sebagai interpreter untuk mendampingi 54 rombongan wisatawan. Kegiatan tersebut dinyatakan cukup berhasil, wisatawan senang bisa belajar adat masyarakat dan lingkungan wonokitri aspek pertanian mulai dari pembibitan, perawatan, sampai ke penanamannya. Selain itu dukungan Kepala Desa Wonokitri dan Tokoh Masyarakat dalam Menyongsong Desa Wisata Edelweis TNBTS pertama di Desa Wonokitri. Kepala Desa Wonokitri memberikan dukungan penuh terhadap pengembangan desa wisata Edelweis di Desa Wonokitri dan berharap bisa menjadikan desa Edelweis sebagai icon atau label khusus bagi Desa Wonokitri. Selain itu, Kepala Desa Wonokitri memfasilitasi lahan seluas 25 x $25 \mathrm{~m} 2$ untuk ditanami Edelweis.
Disamping itu, Ketua RT Desa Wonokitri yang terdiri dari 25 RT, memberikan dukungannya melalui surat pernyataan untuk menanam Edelweis dalam rangka pembentukan desa Edelweis. Berdasarkan dari hasil rekapan surat pernyataan dibutuhkan bibit Edelweis sebanyak 5690 bibit. Dimana bibit-bibit tersebut akan ditanam di halaman rumahrumah warga.

Masyarakat mempercayakan Desa Edelweis di gerakkan oleh Pemuda Desa Wonokitri dan Ibu-ibu PKK sebagai pendukung dalam mensukseskan penanaman Edelweis dirumah. Harapannya ke depan, Desa Wonokitri dapat menjadi desa wisata Edelweis yang dapat menarik minat wisatawan, sehingga pengunjung Bromo tidak hanya dapat berwisata ke Bromo saja akan tetapi dapat mengunjungi Desa Wisata Edelweis Wonokitri

Kanto (2006) membedakan perubahan sosial berdasarkan aspek waktu, dampak dan prosesnya. Jika melihat pada aspek waktu yang dibutuhkan, perubahan sosial di Wonokitri terjadi dalam kurun waktu relatif cepat. Hal tersebut berdasarkan pendapat masyarakat Wonokitri yang menilai bahwa perubahan di wilayahnya berlangsung cepat atau revolusi. Memang dalam hal cepat atau lambatnya waktu perubahan, tidak ada acuan khusus dan bersifat relatif. Akan tetapi, yang menjadi acuan mengenai 
cepatnya perubahan sosial di Wonokitri adalah tingginya semangat masyarakat Wonokitri untuk berbenah, sehingga jika dibandingkan dengan wilayah desa lainnya, Wonokitri adalah yang paling cepat dalam melakukan perubahan. Hal tersebut sebagaimana Sztompka (2010) yang menyatakan bahwa aturan struktural yang melibatkan waktu tidak hanya terbatas pada aspek lamanya saja, tetapi pada kecepatan proses sosial yang terjadi.

Melihat aspek dampak yang ditimbulkannya, maka perubahan di Wonokitri merupakan perubahan sosial karena memiliki dampak yang sangat besar bagi kehidupan sosial di masyarakat Wonokitri. Artinya, perubahan di Wonokitri tidak terbatas pada perubahan pada kondisi lingkungannya saja, tetapi berpengaruh terhadap pola hidup masyarakatnya secara signifikan. Pola hidup masyarakat Wonokitri yang mengalami perubahan meliputi: 1) meningkatnya kesadaran masyarakat untuk menanam tanaman edelweiss dan menjaga lingkungannya, 2) meningkatnya pola interaksi masyarakat menjadi semakin guyub, 3) adanya tambahan ekonomi rumah tangga dari berbagai program wisata bromo sekitarnya yang menghasilkan bagi masyarakat,

Berdasarkan aspek proses terjadinya, perubahan sosial di Wonokitri termasuk perubahan yang disengaja dan direncanakan. Hal tersebut dikarenakan perubahan sosial di Wonokitri tidak akan terjadi tanpa adanya pihak-pihak yang menginisiasi untuk melakukan perubahan. Pihak yang menginisiasi tersebut merupakan agen perubahan yang mana dalam melakukan tindakannya, agen dipengaruhi oleh rasionalitas dalam dirinya dan dorongan struktur yang ada di sekitarnya. Sebagaimana perubahan yang direncanakan pada umumnya, perubahan sosial di Wonokitri telah mengarahkan kondisi di Wonokitri dari yang semula stagnan dari aspek perekonomian sekarang menjadi ramai dari aktivitas ekonomi (wisata bromo: mulai jeep, driver, home stay, kerajinan dan lain-lain).

Dalam realitas kehidupan bermasyarakat, keberadaan ruang dan waktu menjadi faktor yang penting dalam dinamika sosial. Giddens (2010, hlm. 182) menyatakan bahwa ruang dan waktu berkenaan dengan pengekangan yang membentuk rutinitas kehidupan sehari-hari dan menekankan pada sifat praktis, dalam perjumpaan dan bagi terbentuknya perilaku sosial. Gagasan tersebut menunjukkan bahwa ruang dan waktu tidak hanya dipandang sebagai arena, tetapi menjadi setting dari berbagai praktik dan rutinitas sosial. Dalam realitasnya, agen akan dibentuk dan membentuk struktur dalam perentangan ruang dan waktu yang melatarbelakangi berbagai interaksinya. 
Demikian pula yang terjadi dalam perubahan sosial di Desa Wonokitri menjadi Desa Wisata yang mana berlangsung dalam setting ruang dan waktu yang melatarbelakangi prosesnya. Selain itu, ruang dan waktu juga merupakan sarana interaksi dan berlangsungnya berbagai praktik sosial yang kemudian menjadi rutinitas hingga merubah kondisi lingkungan dan sosial masyarakat Wonokitri.

Argumentasi Giddens mengenai pentingnya ruang dan waktu dalam perubahan tersebut menjadi dasar untuk mendeskripsikan tahapan terjadinya perubahan di Wonokitri. Dalam tahapan perubahan Wonokitri, yang dimaksud ruang adalah wilayah cakupan dari proses perubahan yang terjadi. Sedangkan yang dimaksud waktu dalam tahapan perubahan ini merupakan kisaran tahun berlangsungnya proses perubahan di wilayah cakupan tersebut. Ruang dan waktu dalam tahapan perubahan ini penting karena merupakan aspek yang menjadi unsur konstitutif dari interaksi dan praktik sosial yang dilakukan agen dengan strukturnya sehingga berhasil merubah Wonokitri menjadi lebih baik.

Tahapan perubahan sosial yang ada di Wonokitri, diawali pada tahun 2000 yang mana perubahan sudah dimulai pada lingkup personal (Kepala Desa), yakni cakupan pembukaan access jalan Desa
Wonokitri menuju Kawah Bromo untuk wisatawan. Perubahan pemilikan jeep awalnya hanya 3 jeep (pada tahun 2000) kemudian menjadi 180 jeep (pada tahun 2019). Tidak hanya jeep, tapi pembangunan home stay juga sangat cepat, selanjutnya transaski ekonomi khususnya penjualan makan minuman dan kerajinan ataupun persediaan syal, kaos kaki, kaos tangan dan lain-lain juga.

\section{Agen dan Struktur beserta Perannya dalam Perubahan Sosial di Desa Wonokitri}

Dalam perubahan sosial yang terjadi di Desa Wonokitri, terdapat keterlibatan dari pihak-pihak yang menginginkan perubahan. Hal tersebut karena perubahan sosial di Wonokitri termasuk perubahan yang prosesnya direncanakan sehingga ada pihak yang menginginkan terjadinya perubahan. Pihak yang menginginkan perubahan tersebut dalam tulisan ini disebut sebagai agent of change. Keberadaan agent of change menjadi sangat penting karena kondisi perubahan Wonokitri merupakan hasil dari upaya awalnya dalam mengajak berubah. Hal tersebut sebagaimana Hook (dalam Sztompka, 2010) yang menyatakan bahwa perubahan sosial merupakan prestasi aktor manusia, hasil dari tindakan mereka. Merujuk argumentasi tersebut, maka perubahan sosial di Wonokitri merupakan 
hasil dari tindakan masyarakat Wonokitri yang diawali oleh agen pencetus perubahan (kepala desa tahun 2000an). Nama Desa Wisata merupakan simbolisasi hasil prestasi dari upaya yang digagas oleh agen pencetus perubahan yang kemudian berhasil mendapat dukungan dari masyarakatnya.

Dalam perubahan sosial Desa Wonokitri, terdapat tiga agen utama (kalangan tayuban/teropan: pardi, dan budi, kalangan wisata jeep dan homestay: sukir). Peran yang dilakukannya dalam perubahan sosial adalah dengan sosialisasi, berkoordinasi, bersinergi dan kerjasama. Struktur yang ada berasal dari masyarakat Wonokitri beserta praktik sosialnya yang dilatarbelakangi kesadaran praktis dan diskursifnya serta peran tokoh masyarakat (Kepala Desa: Pak Iksan), tokoh adat (Ketua Adat: Pak Kadik) melalui kebijakan strukturalnya. Hubungan antara agen dengan struktur dalam perubahan terjadi melalui skema struktur dominasi (penguasaan agen terhadap struktur), berlanjut signifikansi (ajakan agen pada struktur), dan mencapai skema legitimasi (pembenaran atas upaya agen oleh struktur). Sebenarnya ketiga agen diatas adalah melanjutkan dari tokoh kepala desa pada tahun 2000 (Pak Wartono) dipengaruhi oleh motivasinya yakni ingin menjadikan desa Wonokitri menjadi Desa Wisata kemudian melakukan kerjasama dengan pemerintah pusat (kementrian
Wisata, dan Kehutanan) untuk membuka access jalan Desa Wonokitri menjadi Access Jeep untuk menuju Ke Penanjakan, Kawah Bromo dan lainnya. Sehingga di Wonokitri mengalami perubahan dan dikenal sebagai Desa Wisata.

Argumentasi Giddens mengenai agen dalam perubahan menyatakan bahwa agen perubahan terwujud dari dalam diri individu, bukan berasal dari kehidupan kolektif yang menginginkan perubahan (Giddens (1984), dalam Sztompka, 2010). Argumentasi tersebut sebagaimana terjadi pada fenomena perubahan sosial Wonokitri, yang mana motivasi agen dalam melakukan perubahan muncul dari dalam diri agen melalui pengetahuannya mengenai lingkungan yang baik karena dipengaruhi kondisi struktur masyarakat Wonokitri yang stagnan. Dari pemahaman agen terhadap strukturnya tersebut, sehingga agen mulai melakukan tindakannya untuk merubah struktur yang ada menjadi lebih baik. Hal tersebut karena kedudukan individu dalam struktur adalah sebagai agen atau pelaku yang menunjuk pada orang yang kongkret dalam arus keberlanjutan tindakan dan berbagai peristiwa (Priyono, dalam Basis, 49/01-02/2000).

Giddens (2010) menyatakan bahwa tindakan adalah pengalaman yang diresapi dan bergantung pada perhatian refleksif aktor serta merupakan intervensi sebab-akibat manusia yang direnungkan 
dalam kehidupannya. Argumentasi tersebut sebagaimana yang terjadi pada tindakan agen pencetus perubahan di Wonokitri yang dipengaruhi keseharian masyarakat Wonokitri yang lama hidup dalam rutinitas. Melihat rutinitas masyarakat Wonokitri tersebut, agen melalui kesadaran diskursifnya, yakni kesadaran yang dapat dijelaskan secara verbal oleh aktor (Giddens, dalam Priyono, 2003) memiliki keinginan merubah kondisi tersebut menjadi lebih baik sesuai dengan pemahamannya. Hal tersebut menunjukkan bahwa masyarakat merupakan struktur yang ada di luar agen yang keberadaannya tidak dapat dikesampingkan karena mempengaruhi refleksivitas agen dalam melakukan tindakannya.

Dari tindakan agen terhadap strukturnya tersebut, sehingga struktur yang telah lama ada mengalami perubahan sebagai akibat dari munculnya kesadaran praktis di masyarakat setelah dilakukan pembiasaan oleh agen. Dalam konteks ini, agen dibentuk dan membentuk struktur. Agen dibentuk struktur karena dalam melakukan tindakannya untuk merubah Wonokitri, diciptakan dari adanya keterulangan praktik sosial yang telah lama ada di masyarakat Wonokitri yang direfleksikannya melalui kesadaran yang dimilikinya. Sementara agen dikatakan membentuk struktur karena melalui upaya yang dilakukannya telah membawa kondisi masyarakat Wonokitri menjadi lebih baik karena adanya reproduksi struktur dengan berbagai praktik sosial baru yang diciptakannya melalui keterulangan dalam rutinitas kehidupan masyarakat Wonokitri.

Dalam fenomena perubahan sosial yang ada di Desa Wonokitri, agen perubahan memiliki perannya tersendiri yang berlangsung mulai dari agen tersebut berinisiatif melakukan perubahan, hingga kondisi Wonokitri mengalami perubahan yang pesat dan menjadi Desa Wisata seperti saat ini. Peran dan upaya yang dilakukan oleh agen perubahan tersebut tentunya tidak serta-merta dilakukan dengan cara yang mudah dan cepat, tetapi membutuhkan waktu serta melalui berbagai proses yang bertahap. Hal tersebut karena dalam mengajak masyarakat untuk kreatif dan tetap menjalankan adat seperti biasanya. Hasilnya atas kegigihan yang dilakukan oleh agen pencetus perubahan sehingga pada akhirnya masyarakat justru mendukung berbagai upaya yang dilakukan oleh agen tersebut.

Praktik sosial yang dilakukan oleh agen perubahan Wonokitri dipengaruhi oleh faktor internal dari dalam dirinya berupa kesadaran diskursif (nalar) yang menentukan konsistensi atas tindakan yang dilakukannya dalam mengajak masyarakat untuk berbenah. Kesadaran diskursif tersebut memunculkan alasan yang tertanam dalam pemahaman agen mengenai 
kondisi lingkungan dan masyarakat yang ideal sesuai keinginannya. Alasan tersebut mendorong agen sehingga melakukan berbagai praktik sosial di masyarakat hingga pada akhirnya menunjukkan adanya ketercapaian sebagaimana tujuan awal yang diinginkannya. Ketercapaian tersebut berupa semakin banyaknya masyarakat yang mengikuti praktik sosial sebagaimana dilakukan oleh agen. Dengan capaian tersebut, agen termotivasi untuk mewujudkan sesuatu yang lebih dari tujuan awalnya. Jika pada mulanya agen hanya bertujuan ingin merubah kondisi lingkungan dan masyarakat di sekitar tempat tinggalnya yang stagnan menjadi sadar lingkungan, lambat laun dengan berbagai keberhasilan yang dicapai, agen memiliki keinginan lain yang memotivasinya untuk terus melakukan praktik sosialnya bersama masyarakat dengan cakupan yang lebih luas.

Motivasi yang menjadi keinginan agen tersebut berupa potensi diraihnya penghargaan bidang lingkungan di wilayahnya, agen merasa bahwa prestasi tersebut dapat dimanfaatkan untuk merubah kondisi wilayah lainnya di Wonokitri. Motivasi tersebut kemudian didukung oleh struktur yang ada di luar agen, yakni masyarakat dan pihak Desa Wonokitri yang kemudian secara bersama-sama melakukan praktik sosialnya untuk meraih lebih banyak penghargaan di bidang wisata.

$$
\text { Giddens (2010, hlm. }
$$
menyatakan bahwa dalam melakukan agensi atau tindakannya, agen akan melakukan monitoring refleksif atas tindakannya. Dalam monitoring refleksif yang dilakukan oleh agen, agen tidak hanya memonitor aktivitasnya dan berharap orang lain untuk mengikuti aktivitas tersebut saja, tetapi agen juga secara rutin memantau aspek-aspek yang melatarbelakangi berbagai aktivitas tersebut baik fisik maupun sosial. Dalam fenomena perubahan sosial Desa Wonokitri, agen pencetus perubahan juga melakukan monitoring refleksif terhadap praktik sosialnya. Merujuk pada definisi Giddens tersebut, maka agen pencetus perubahan di Desa Wonokitri tidak hanya memantau rutinitas yang dilakukannya untuk menjadikan Desa Wisata, tetapi agen juga memantau berbagai aspek dan kemungkinan yang berkaitan dengan tindakannya tersebut.

$$
\text { Aspek-aspek yang menjadi }
$$
pertimbangan agen tersebut seperti respon masyarakat sekitar terhadap upaya yang dilakukannya, ketersediaan fasilitas yang diperlukan untuk melakukan tindakannya, serta prediksi dari tindakannya di masa mendatang. Aspek-aspek tersebut menjadi sasaran awal monitoring yang dilakukan oleh agen dengan maksud untuk menghindari hal-hal yang terjadi di luar keinginan agen. Dengan begitu, agen dapat mengantisipasi dan mencarikan solusi 
terhadap situasi- situasi di luar keinginan agen tersebut. Selain itu, dengan melakukan monitoring refleksifnya, agen akan menemukan potensi-potensi yang berguna untuk mendukung upayanya mencapai kondisi lingkungan dan masyarakat di sekitarnya yang lebih baik sebagaimana tujuan yang diinginkannya.

Jika dirunut berdasarkan ruang dan waktu, praktik sosial yang dilakukan oleh agen dalam proses perubahan dimulai melalui tahap sosialisasi, yakni dengan cara memberi contoh melalui tindakan yang dilakukan agen secara berulang dan berupa ajakan agen kepada masyarakat sekitarnya, mulai dari lingkup tetangga terdekatnya hingga lingkup yang lebih luas agar mengikuti tindakannya. Dengan dilakukannya sosialisasi oleh agen kepada masyarakatnya secara terus-menerus, dukungan dari masyarakat kepada agen semakin bertambah. Dengan bertambahnya dukungan masyarakat, kemudian agen melakukan persuasi untuk usaha yang bias dimanfaatkan sector wisata. Cara ini dilakukan ketika semakin banyak masyarakat yang mengikuti dan mendukung upaya agen untuk merubah lingkungan. Dengan terbentuknya pengetahuan baru di masyarakat, maka perubahan sosial di Desa Wonokitri menjadi lebih cepat tercapainya karena ada keterlibatan langsung dari masyarakat.
Setelah pemahaman di masyarakat Desa Wonokitri mengenai berbagai inovasi di bidang lingkungan semakin bertambah dengan adanya usaha, agen kemudian mengajak masyarakatnya untuk memberi pelayanan kepada wisatawan (tamu). Hal tersebut dilakukan dengan cara memberi pelayanan terbaik kepada wisatawan yang dating ke Desa Wonokitri. Hal tersebut juga diiringi dengan koordinasi berbagai pihak atau kerjasama dengan berbagai rekanan (agent tour travel). Sehingga akan tercipta suasana system yang baru dan dinamis.

Namun demikian juga ada kesepakatan berkenaan dengan jeep yang bukan dari paguyuban jeep tidak boleh masuk ke acces jalan Desa Wonokitri (memasuki wisata Bromo).

Dalam melakukan perannya yang terwujud melalui praktik sosial tersebut, agen memiliki rasionalisasi terhadap tindakannya. Giddens (2010, hlm. 8) mendefinisikan rasionalisasi tindakan sebagai upaya agen yang secara rutin dan tanpa perdebatan mempertahankan suatu "pemahaman teoretis" tentang landasanlandasan aktivitas mereka. Merujuk pada pengertian tersebut, maka dalam menjaga keberlangsungan dan keberlanjutan perannya, agen-agen pencetus perubahan di Desa Wonokitri akan melakukan rasionalisasi terhadap tindakannya. Rasionalisasi tindakan dilakukan oleh agen ketika ada pihak-pihak yang 
mempertanyakan atau bahkan menentang praktik sosial yang dilakukan oleh agen dalam mewujudkan keinginan awalnya untuk merubah kondisi lingkungan dan masyarakat sekitarnya. Rasionalitas tindakan yang dilakukan oleh agen perubahan Desa Wonokitri bukan merupakan alasan yang melatarbelakangi dari tindakannya secara diskursif, melainkan lebih pada kemampuan dan pengetahuan yang dimiliki oleh agen untuk dapat menjelaskan secara rinci terhadap tindakannya tersebut jika ada yang meminta.

Rasionalitas agensi dimiliki oleh agen melalui pengetahuan yang dimilikinya. Pengetahuan tersebut menjadi bekal yang dimiliki oleh agen jika sewaktuwaktu mendapati pihak yang mempertanyakan upaya yang dilakukannya serta pihak yang berpotensi mengganggu upaya agen tersebut. Intinya, pengetahuan yang dimiliki oleh agen akan berguna untuk merasionalkan tindakannya kepada orang lain. Pengetahuan tersebut misalnya: pemahaman agen mengenai pemerataan atau jadwal jeep dalam pelayanan tamu serta pelayanan home stay. Semuanya tergantung dari rekanan atau stakeholders lainnya.

Dengan begitu, jika ada pihakpihak dari masyarakat yang menentang upaya agen tersebut, maka dengan pengetahuannya, agen perubahan akan menjelaskan maksud dari tindakannya dan berupaya meyakinkan pihak tersebut mengenai upayanya. Penjelasan oleh agen tersebut dimaksudkan agar masyarakat dapat menerima pemikiran dan tindakan yang dicontohkan oleh agen yang didasari keinginan agen tersebut. Agen tersebut tidak akan mudah terpengaruh dengan adanya pihak-pihak yang kontra, tetapi justru mendekati pihak-pihak tersebut secara rutin dan intensif agar kemudian dapat bekerjasama. Dengan rasionalitas agensi yang dimiliki oleh agen perubahan di Desa Wonokitri tersebut, sehingga "proyek" perubahan tidak hanya menjadi tanggung jawab agen saja, tetapi kemudian menjadi tanggung jawab agen dan struktur yang secara bersama-sama melakukan reproduksi terhadap struktur masyarakat yang telah lama ada yang diaplikasikan dengan dibentuknya kepengurusan struktural dan berbagai program yang berkaitan dengan pola hidup sadar lingkungan untuk menindaklanjuti upaya awal yang digagas oleh agen.

Giddens menyebut teorinya dengan nama 'struktur-asi' sebagai penunjuk pada berlangsungnya proses (dalam Priyono, 2003). Jika dihubungkan dengan pentingnya aspek ruang dan waktu, maka strukturasi menunjukkan adanya proses yang berlangsung pada tataran struktur. Artinya, dalam ruang dan waktu tidak hanya terjadi tindakan yang dilakukan 
oleh agen semata, tetapi juga terjadi berbagai peristiwa yang berkaitan dengan struktur sosial. Hal tersebut oleh Giddens (dalam Priyono, 2003) disebut sebagai dualitas agen-stuktur, yakni hubungan yang saling melengkapi antara agen dan struktur. Artinya, agen dan struktur merupakan dua hal yang tidak dapat dilepaskan keterkaitannya dalam mengkaji suatu fenomena sosial.

Jika dihubungkan dalam konteks fenomena perubahan sosial yang terjadi di Desa Wonokitri untuk melihat peristiwa perubahan yang terjadi, maka tidak cukup jika hanya mengetahui agen pencetus perubahan yang ada di Desa Wonokitri dan praktik sosial yang dilakukannya saja. Akan tetapi, untuk melihat peristiwa perubahan yang terjadi Desa Wonokitri secara utuh, maka harus mengetahui pula struktur yang ada di Desa Wonokitri sepanjang ruang dan waktu pada tahap terjadinya perubahan. Hal tersebut karena struktur merupakan hasil dari berlangsungnya praktik sosial agen, sekaligus sarana berlangsungnya praktik sosial agen. Artinya, struktur merupakan bentukan dari agen sekaligus membentuk agen tersebut dalam tindakannya.

Dalam konteks penelitian ini, struktur merupakan pihak yang menjadi pemicu agen dalam tindakannya yang pada akhirnya memberi banyak pengaruh pada struktur itu sendiri. Struktur yang dimaksud dalam penelitian ini terdiri dari seluruh elemen masyarakat Desa Wonokitri beserta praktik sosial mereka serta pihak pemerintah dari Desa Wonokitri. Struktur yang menjadi pemicu serta target perubahan yang dimulai oleh agen pencetus perubahan. Masyarakat Desa Wonokitri dan pemerintah menjadi pemicu dari munculnya motivasi agen pencetus perubahan yang kemudian diwujudkan melalui tindakannya pada struktur tersebut sehingga kemudian kondisi yang ada di berbagai aspek masyarakat Gundih mengalami perubahan.

Yang menjadi struktur utama dari perubahan sosial yang ada di Desa Wonokitri ialah masyarakat Desa Wonokitri beserta "aturan" yang ada dalam kehidupan sosial mereka. Hal tersebut dikarenakan masyarakat merupakan hal utama yang mempengaruhi agen sehingga melakukan perannya dalam perubahan di Desa Wonokitri. Kondisi awal struktur masyarakat Desa Wonokitri yang stagnan dan pasif serta kemiskinan yang melatar belakangi agen. Dari hal tersebut kemudian memotivasi agen untuk melakukan tindakan perubahan. Sehingga sangat jelas bahwa struktur masyarakat Desa Wonokitri berperan dalam mendorong agen memulai melakukan perubahan.

Hubungan antara agen dengan struktur dalam proses perubahan Desa Wonokitri menunjukkan terjadinya dualitas. Dualitas tersebut terdapat pada agen melalui kesadaran diskursifnya mulai 
melakukan berbagai upaya agar strukturnya dapat berubah. Setelah struktur masyarakat dalam lingkup wilayah tempat tinggal agen tersebut menunjukkan hasil perubahan yang nyata, kemudian menyebar pada seluruh wilayah yang ada di Desa Wonokitri. Pada tataran struktur, terdapat aspek kesadaran praktis yang dimiliki oleh masyarakat Gundih yang melekat pada kehidupan mereka yang terbentuk melalui berbagai keterulangan tindakan beserta aturan yang pada mulanya dicontohkan oleh agen, kemudian diikuti dan dilakukan oleh warga Desa Wonokitri secara mandiri melalui praktik sosial dan interaksinya. Dari kesadaran praktis yang dilakukan terusmenerus, kemudian terjadi berbagai dinamika yang menghasilkan Desa Wonokitri pada kondisinya saat ini yang mana masyarakatnya telah sadar dan peduli pada kondisi lingkungannya.

Selain kesadaran praktis, tindakan masyarakat Desa Wonokitri juga dipengaruhi aspek kesadaran diskursif yang mendorong partisipasi mereka dalam perubahan. Kesadaran diskursif tersebut muncul setelah masyarakat merefleksikan kesadaran praktisnya dengan melihat hasil serta capaian perubahan yang terjadi sehingga semakin termotivasi untuk melakukan berbagai tindakan dan inovasi untuk menjaga kondisi perubahan yang telah dicapai. Kesadaran praktis dan diskursif yang dimiliki oleh masyarakat
Desa Wonokitri saat ini terwujud melalui rutinitas praktik sosial keseharian mereka yang mana perilaku masyarakatnya sekarang tetap menjalankan adat tengger, aktivitas pertanian dan wisata (hal baru) sesuai dengan peran masing-masing.

Selain struktur dari masyarakat yang menjadi faktor eksternal agen dalam menginisiasi perubahan tersebut, terdapat faktor lain yang juga menjadi struktur bagi berlangsungnya praktik sosial di masyarakat Desa Wonokitri, yakni dari aspek struktur pemerintahan yang ada di Desa Wonokitri. Struktur pemerintahan tersebut terdiri dari Pemkab PAsuruan, Kementrian Kehutanan dan Kementrian Pariwisata dan Budaya. Peran dari instansi pemerintah tersebut sangat penting bagi berlangsungnya proses perubahan yang terjadi di Desa Wonokitri tersebut. Hal tersebut karena pemerintah melalui kebijakannya juga turut berperan dalam merangsang semangat masyarakat dalam perubahan, meskipun peran struktur yang dominan ada pada masyarakat dan kehidupan sosialnya di Desa Wonokitri.

\section{Hubungan Agen dengan Struktur dalam Perubahan Sosial di Desa Wonokitri \\ Dalam fenomena perubahan sosial} yang terjadi di Desa Wonokitri sehingga menjadikannya dikenal sebagai Desa Wisata, terdapat hubungan dualitas yang terjalin antara agen pencetus perubahan 
dengan struktur yang ada. Hubungan tersebut terwujud dalam peran agen dan struktur yang saling mempengaruhi dan terjadi dalam momentum ruang dan waktu. Hubungan tersebut diawali oleh upaya agen pencetus perubahan untuk meningkatkan kondisi perekonomian melalui wisata dan masyarakatnya yang telah lama hidup dalam kondisinya yang stagnan (banyak upacara adat namun aspek perekonomian kurang). Upaya tersebut terwujud dalam praktik sosial yang dilakukan oleh agen dalam tindakannya melakukan kerjasama dan pembukaan desa wisata dengan bekerjasama berbagai pihak.

Jika mengacu pada gagasan Giddens (2010) mengenai tiga dimensi struktural dalam praktik sosial (signifikansi, dominasi dan legitimasi), maka terjalinnya hubungan yang saling mempengaruhi antara agen pencetus perubahan dengan struktur yang ada dalam kehidupan masyarakat Desa Wonokitri terjalin melalui ranah politis ketika agen memiliki kekuasaan terhadap masyarakat Desa Wonokitri, yakni melalui skema dominasi, signifikansi dan legitimasi. Dimulai pada tahap dominasi, yakni struktur yang berkaitan dengan penguasaan orang (politik) dan barang (ekonomi) melalui sarana fasilitas yang tersedia (Priyono, 2003, hlm. 24). Dominasi agen terhadap strukturnya dimulai ketika masyarakat yang ada di sekitar tempat tinggal agen mulai melihat adanya keberhasilan dari upaya yang dilakukan oleh agen tersebut. Keberhasilan tersebut berupa banyaknya tamu atau wisatawan domestic maupun internasional, meningkatnya pemilik homestay, penjual makanan minuman, penjual atau penyewa berbagai bekal ke bromo, driver jeep, pemilik jeep dan lainlain. Sehingga mampu meningkatkan secara perekonomian.

Puncak dari kepercayaan masyarakat terwujud ketika masyarakat mempercayakan kalangan pemuda (Mas Sukir) menjadi bagian dari apparat desa (wakil divisi wisata di Desa Wonokitri) kepada agen tersebut. Dengan diangkatnya agen perubahan tersebut menjadi wakil divisi wisata, maka agen tersebut telah mendominasi masyarakat Desa Wonokitri, terutama di wilayah terlebih dahulu. Dominasi tersebut kemudian semakin mempermudah agen dalam melakukan perubahan di lingkungannya karena agen tersebut telah "menguasai dan mengontrol" masyarakat sehingga apapun yang disarankannya pada masyarakat akan dilakukan dan didukung oleh masyarakat. Dengan posisi yang diperoleh agen tersebut di masyarakat, ajakan yang dilakukan oleh agen kepada masyarakat akan dilakukan dengan tanggapan dan respon positif. Posisi tersebut tidak disia-siakan oleh agen dengan membentuk struktur kepengurusan yang melibatkan semua masyarakat di sekitarnya. 
Setelah melalui skema dominasi, hubungan antara agen perubahan Desa Wonokitri dengan strukturnya berlanjut pada skema struktur signifikansi, yakni skema simbolik atau penandaan yang menyangkut penyebutan, pemaknaan dan wacana (Priyono, 2003). Pada skema ini, agen perubahan melalui kesadaran diskursif yang dimilikinya mengkomunikasikan berbagai pengetahuan yang dimilikinya kepada masyarakat melalui contoh tindakan dan ajakannya kepada masyarakat secara agar melakukan hal serupa, yakni mengenai meningkatkan rating wisata, kerjasama dengan agent tour travel, layanan online dan lain-lain). Dari hal tersebut kemudian terjadi keterulangan yang menjadi rutinitas kehidupan sosial masyarakat Desa Wonokitri sehingga membentuk praktik sosial yang baru bagi masyarakat Desa Wonokitri.

Skema signifikansi pada tataran struktur masyarakat Desa Wonokitri terjadi setelah agen perubahan melalui kontinuitas praktik sosialnya mampu menyebarluaskan tindakannya dan menjangkau seluruh masyarakat Desa Wonokitri dalam lingkup ruang dan kurun waktu satu tahun. Keberadaan ruang dan waktu dalam skema signifikansi pada tataran struktur masyarakat Desa Wonokitri menjadi unsur penting yang mana dalam ruang dan waktu tersebutlah kemudian masyarakat Gundih mengalami reproduksi pada strukturnya sehingga mengarahkan pada terjadinya perubahan di Desa Wonokitri. Keberhasilan agen diawali melalui praktik sosialnya dengan memberi contoh pada lingkup wilayah sekitar tempat tinggalnya yang menjadi ruang agen dalam melakukan praktik komunikasinya pada masyarakat dalam waktu yang relatif singkat. Dikatakan relatif singkat karena waktu yang dibutuhkan agen untuk mendapat kepercayaan masyarakat melalui tindakan yang dicontohkannya pada masyarakat hanya terjadi kurang dari satu tahun proses.

Setelah skema signifikansi yang terjalin melalui tindakan sosialisasi agen kepada masyarakat mengenai manfaat adanya desa wisata (semakin banyak pengunjung) dengan mendapatkan tambahan secara ekonomi, hubungan yang terjalin antara agen dengan struktur dalam perubahan sosial Desa Wonokitri berlanjut pada fase legitimasi, yakni struktur yang menyangkut pembenaran atas peraturan normatif yang ada dalam tata hukum (Giddens, dalam Priyono, 2003). Giddens menyebut struktur legitimasi tersebut sebagai sistem kaidah moral (Giddens, 2010, hlm. 173). Pada fase legitimasi, dualitas agen dengan struktur berlanjut pada tataran pembenaran oleh struktur masyarakat Desa Wonokitri secara lebih luas. Artinya, tidak hanya masyarakat yang ada di sekitar tempat tinggal agen saja yang membenarkan upaya agen tersebut, tetapi 
masyarakat Desa Wonokitri secara menyeluruh juga turut mendukung dan membenarkan upaya yang diawali oleh agen dalam melakukan perubahan tersebut.

Dukungan dari seluruh masyarakat Desa Wonokitri tersebut tidak serta merta muncul karena upaya agen saja, tetapi karena adanya dukungan dominasi struktur dari pihak Desa Wonokitri yang turut melakukan legitimasi terhadap upaya agen. Legitimasi yang diberikan oleh pihak Kelurahan Gundih tersebut berupa dukungan terhadap upaya agen melalui berbagai aturan dan program yang berkaitan pengelolaan wisata (tamu, jeep, home stay dan lain-lain).

Kebiasaan masyarakat untuk bersinergi satu sama lain dan melengkapi dalam pelayanan wisata menjadi norma tersendiri yang mengikat kehidupan sosial masyarakat Desa Wonokitri. Dalam penerapan norma tersebut, terdapat sanksi yang bersifat sosial sehingga mereka cenderung untuk menjaga diri agar tidak melanggar norma tersebut, meskipun dalam penerapannya tidak ada aturan tertulis.

Aturan-aturan tersebut pada mulanya berguna untuk membiasakan masyarakat agar tidak asing dengan kebiasaan baru untuk menggantikan kebiasaan lama mereka yang hidup dalam kondisi stagnan. Dalam merubah kebiasaan yang telah lama ada di masyarakat, tidak dapat dilakukan dengan instan, tetapi melalui beberapa tahap pembiasaan yang mana dengan adanya aturan yang bersifat "memaksa" akan mengekang masyarakat dalam praktik sosialnya yang baru. Selain itu, sanksi juga diterapkan ketika ada warga yang melanggar aturan-aturan tersebut. Sanksi-sanksi tersebut berupa teguran langsung oleh tetangga, Ketua RT dan lainnya. Fokus masyarakat adalah memberikan pelayanan barang dan jasa pada tamu atau wisatawan. Berikut adalah ringkasan mengenai hubungan dualitas agen dengan struktur dalam perubahan sosial Desa Wonokitri sebagaimana dalam tabel 1: 
Tabel 1. Hubungan dualitas agen-struktur

\begin{tabular}{|c|c|c|}
\hline Tataran Interaksi Agen & Sarana/ Modalitas & Tataran Struktur \\
\hline $\begin{array}{l}\quad \underline{\text { Kekuasaan }} \\
\text { Agen memiliki wewenang } \\
\text { lebih untuk mengarahkan } \\
\text { masyarakat agar } \\
\text { memberikan pelayanan } \\
\text { wisata yang baik (jeep, } \\
\text { home stay dan lain-lain). }\end{array}$ & $\begin{array}{l}\text { Agen dipercaya menjadi } \\
\text { fasilitator dalam } \\
\text { pengembangan wisata yang } \\
\text { sesuai dengan porsinya }\end{array}$ & $\begin{array}{l}\text { Dominasi } \\
\text { Melihat adanya keberhasilan } \\
\text { prestasi dalam wisata, } \\
\text { masyarakat mempercayai } \\
\text { agen untuk menjadi } \\
\text { pemimpin di wilayahnya } \\
\text { (Misal Mas Sukir jadi Wakil } \\
\text { Divisi Wisata). }\end{array}$ \\
\hline $\begin{array}{l}\text { Komunikasi } \\
\text { Agen mengajak dan } \\
\text { contoh } r \text { tindakan rad pada } \\
\text { masyarakat mengenai } \\
\text { pelayanan wisata. }\end{array}$ & \begin{tabular}{l}
\multicolumn{3}{c}{ Bingkai interpretasi } \\
Agen mensosialisasikan \\
manfaat usaha (pendapatan \\
secara ekonomi), Desa \\
Wisata Wonokitri lebih \\
terkenal, semakin dipercaya \\
oleh pengunjung. Dan \\
Masyarakat sekiat \\
mendapatkan banyak \\
manfaat (secara ekonomi)
\end{tabular} & $\begin{array}{l}\text { Signifikansi } \\
\text { Terciptanya Desa Wisata yang } \\
\text { berkelanjutan (kesejahteraan } \\
\text { dan budaya semakin terjaga } \\
\text { dan lestari). }\end{array}$ \\
\hline $\begin{array}{l}\frac{\text { Sanksi }}{\text { Penerapan aturan tidak tertulis }} \\
\text { berkaitan dengan penerapan } \\
\text { pelayanan pengunjung yang } \\
\text { ramah dan berkelanjutan }\end{array}$ & $\begin{array}{l}\text { Norma } \\
\text { Agen danstruktur } \\
\text { menerapkan berbagai aturan } \\
\text { tentang berbagai aturan } \\
\text { wisata (jeep, home stay, } \\
\text { access penjualan tanah hanya } \\
\text { pribumi wonokitri yang } \\
\text { membeli) dan iuran bagi } \\
\text { wisatawan ke desa wonokitri }\end{array}$ & $\begin{array}{l}\text { Legitimasi } \\
\text { Kebijakan struktural dari Desa } \\
\text { Wonokitri, dibentuknya Divisi } \\
\text { Wisata khusus pengembangan } \\
\text { wisata di Desa Wonokitri. }\end{array}$ \\
\hline
\end{tabular}

\section{Kesimpulan}

1. Terdapat 3 orang agen yang mengawali terjadinya perubahan sosial di Desa Wonokitri, yakni Mas Pardi, Mas Sukir, Mas Budi. Ketiga orang agen tersebut melalui kesadaran diskursifnya memiliki keinginan awal untuk merubah kondisi lingkungan dan masyarakatnya yang semula stagnan menjadi lebih baik menjadi desa wisata yang semakin produktif. Peran yang dilakukan oleh ketiga orang agen pencetus perubahan tersebut meliputi sosialisasi, koordinasi, sinergi dan resiprosity dengan jejaring di luar desa Wonokitri.

2. Pada tataran struktur, terdapat peranan masyarakat Desa Wonokitri beserta praktik sosialnya yang mendorong agen untuk melakukan perubahan terhadap kondisi struktur masyarakat yang telah ada. Atas upaya pembiasaan yang diawali agen tersebut, pada akhirnya masyarakat Desa Wonokitri memiliki kesadaran praktis dan diskursif untuk melakukan rutinitas praktik sosial mereka yang baru. Selain itu, peranan struktur juga berasal dari Pemerintah Desa Wonokitri, Pemkab Pasuruan, Kementrian Kehutanan, Pariwisata dan Budaya dan 
pihak lainnya. Dengan melalui berbagai event dan kebijakannya berkaitan dengan wisata dan budaya.

3. Hubungan dualitas agen dengan struktur yang ada dalam perubahan sosial Desa Wonokitri menjadi Desa Wisata terjalin melalui skema struktur dominasi yang ditandai dengan semakin tingginya kepercayaan masyarakat di sekitar tempat tinggal agen (ruang) terhadap tindakan yang dilakukan oleh agen untuk melakukan perubahan sehingga dipercaya oleh masyarakat untuk menjadi pemimpin di lingkungan tempat tinggalnya sehingga semakin memudahkan agen dalam mempengaruhi masyarakatnya. Kemudian berlanjut pada skema struktur signifikansi yang ditandai munculnya motivasi agen dan strukturnya untuk meraih penghargaan yang lebih banyak dan menjaga keberlangsungan Desa Wisata. Pada akhirnya, skema legitimasi terjadi ketika kekuasaan yang dimiliki oleh agen mendapat dukungan dari kekuasaan yang lebih besar, yakni dari pihak Desa Wonokitri yang kemudian dengan kebijakannya mampu menerapkan aturan dan sanksi di masyarakat dalam rangka mendukung upaya awal yang dilakukan oleh agen dalam melakukan perubahan.

\section{DAFTAR PUSTAKA}

Giddens, Anthony. (2010). Metode sosiologi: Kaidah-kaidah baru. Yogyakarta: Pustaka Pelajar.
Giddens, Anthony. (2010). Teori strukturasi:

Dasar-dasar pembentukan struktur sosial di masyarakat. Yogyakarta: Pustaka Pelajar.

Kanto, Sanggar. (2006). Modernisasi dan perubahan sosial; suatu kajian dari perspektif teori dan empirik. Malang: Unit Penerbitan Fakultas Pertanian Universitas Brawijaya.

Maya, Siti. 2018. Identifikasi Langkah Awal Pengembangan Desa Edelweis Wonokitri. Di access pada 30 November 2019. http://bromotenggersemeru.org/arti cle/identifikasi-langkah-awalpengembangan-desa-edelweiswonokitri

Nasution, Adham. (1983). Sosiologi, Bandung : Alumni

Moleong, Lexy J. (2013). Metodologi penelitian kualitatif; edisi revisi. Bandung: Remaja Rosdakarya.

Priyono, H.B. (2003). Anthony Giddens: suatu pengantar. Jakarta: Kepustakaan Populer Gramedia.

Ritzer, G dan Smart, B. (2014). Handbook Teori Sosial. Diterjemahkan oleh Imam Muttaaqien dan derta S.W. Bandung : Nusa Media.

Salim, A. (2006). Teori \& paradigma penelitian sosial: Buku sumber untuk penelitian kualitatif. Yogyakarta: Tiara Wacana. 
Sztompka, P. (2010). Sosiologi perubahan sosial. Jakarta: Prenada.

Syani, A. (2007). Sosiologi skematika, teori, dan terapan. Jakarta: Bumi Aksara. Yin, R.K. (2013). Studi kasus: Desain \& metode. Jakarta: Raja Grafindo Persada.

Sztomka, Piotr. (2004). Sosiologi Perubahan Sosial. (terjemahan Alimandan). Jakarta: Prenada Media Group. (buku asli diterbitkan tahun 1993)

Supardi

Suparlan.(1984).Masyarakat:Strukt
ursosial,Individu,

KeluargadanMasyarakat. Jakarta: Akademi Presindo

Sugihen,Bahrein T.(1997).Sosiologi Pedesaan(Suatu Pengantar), Jakarta: Raja Grafindo Persada.

Surbakti,R.A.,Mashud, M.,Suyanto.B., et al. (2004). Sosiologi teks pengantar dan terapan (4rded). Jakarta : Prenadameda Group

Wirawan, B.I. (2012). Teori-teori sosial dalam tiga paradigma, Jakarta : Prenadameda Group

*Dosen Fakultas Pertanian Univestitas Brawijaya

(Email: handono@ub.ac.id) 